Article

\title{
Reputation, Game Theory and Entrepreneurial Sustainability
}

\author{
Juan Pineiro-Chousa ${ }^{1}$, Marcos Vizcaíno-González ${ }^{2, *}$ and M. Ángeles López-Cabarcos ${ }^{3}$ \\ 1 Department of Financial Economics and Accounting, Universidad de Santiago de Compostela, \\ Santiago de Compostela 15782, Spain; j.pineiro@usc.es \\ 2 Department of Financial Economics and Accounting, Universidade da Coruña, A Coruña 15071, Spain \\ 3 Department of Business Organization and Commercialization, Universidad de Santiago de Compostela, \\ Santiago de Compostela 15782, Spain; angeles.lopez.cabarcos@usc.es \\ * Correspondence: marcos.vizcaino@udc.es; Tel.: +34-881-012462
}

Academic Editor: Domingo Ribeiro-Soriano

Received: 7 October 2016; Accepted: 15 November 2016; Published: 19 November 2016

\begin{abstract}
This manuscript provides a novel approach to reputational management as a driver of entrepreneurial sustainability, using game theory to integrate three dimensions of reputation. First, if the entrepreneur perceives reputation as a risk source, the analysis is framed as a prisoner's dilemma schema that is solved by protecting against reputational threats from entrepreneurial sustainability. Second, if the entrepreneur perceives reputation as a competitive advantage, the analysis is framed as an innovator's dilemma that is solved by getting reputational opportunities from entrepreneurial sustainability. Third, if reputation is perceived as a strategic asset, the analysis is framed as a coordination game schema that results in the development of a reputational intelligence skill that has the potential to become crucial for success in entrepreneurial sustainability. Consequently, this manuscript provides an original multidisciplinary analysis of reputational management by relating well-known theoretical results from game theory to organizational realities.
\end{abstract}

Keywords: entrepreneurial sustainability; game theory; reputation; reputational intelligence; financial risk

\section{Introduction}

In recent years there has been a turn from plain law obedience to ethical principles because of the increasing relevance of reputation and reputational risk [1]. In this regard, corporate social responsibility and sustainability play a key role [2-4] and, in fact, previous research links sustainability and environmental performance with corporate reputation [5,6], stating that a successful sustainable performance leads to a strong and well-valued reputation [7]. However, academic literature establishes that reputation is affected by a vast number of factors that influence its value, indicating that there is a specific reputation-related risk (or reputational risk), either a downside or upside [8], that needs to be effectively managed just like any other risk source $[9,10]$. In this sense, there is some evidence indicating the key role of a sustainable attitude and its disclosure for an effective reputational risk strategy [11-15].

Reputation and its associated risk have been addressed from different perspectives and realities. Thus, there is a link between reputational effects and operational results in financial institutions $[16,17]$. In addition, banks need to consider their clients' expectations for successful reputational management [18]. There are also some contributions from other fields analysing the importance of reputational management for the insurance industry $[19,20]$, airports, and educational institutions [21,22], among others. 
The aim of this manuscript is to provide a novel approach to reputational management as a driver of entrepreneurial sustainability $[23,24]$, using game theory to integrate three dimensions of reputation. In the first dimension, the entrepreneur can perceive reputation as a risk source. In this situation, the entrepreneur enters into a prisoners' dilemma framework, which has a unique solution when the entrepreneur protects against the reputational threats driven by entrepreneurial sustainability. A second dimension arises when the entrepreneur considers reputation to be a competitive advantage. In this scenario, the entrepreneur enters into an innovator's dilemma schema, which also has a unique solution when the entrepreneur turns innovative ideas into reputational opportunities derived from entrepreneurial sustainability. Finally, a new schema is proposed, based on the entrepreneur fully thinking in reputational terms, with reputation perceived as a core value. This approach leads to a new business philosophy that can be contextualized into a coordination game schema, where reputation permeates every action or decision and, as a final outcome, the results are consistent with the theory of multiple intelligences, allowing the development of a new skill that can be called reputational intelligence. As a result, this manuscript provides an original multidisciplinary analysis of reputational management by relating well-known theoretical results from game theory to organizational realities, considering that an organization can adopt different identities when facing sustainability issues [25] and favoring the appearance of new approaches [26] as well as the reconsideration of the traditional ones [27]. This is done in order to rethink and advance the existing academic knowledge [28-30], taking into account that there is no need for theories of organizations to be exact or general in order to become helpful [31].

The rest of the manuscript is organized as follows. The second section analyzes reputation as a risk source. The third section presents reputation as a competitive advantage. The fourth section describes the concepts of reputational thinking and reputational intelligence. The fifth section integrates the three dimensions of reputation. Finally, the sixth section offers conclusions.

\section{Reputation as a Risk Source}

Due to recent corporate scandals [17], individuals usually perceive reputation as a risk source and, as a consequence, reputational risk management has become an urgent issue for managers and directors in organizations of all kinds [32-35]. Anything that could affect the organizational reputation, the image or the brand is a potential source of reputational risk $[9,10]$, but its management is frequently insufficient or inexistent in numerous organizations [36]. In fact, inadequate management of any risk can lead to reputational damage [37], because reputational risk shows how wide, important and imprecise the risks that may affect an organization can be [38]. This reputational damage can manifest in several different ways. Reduction of present customers and limited access to future customers [39] as well as lost advantages in terms of costs [40] are consequences of reputational damage that can lead the organization to a difficult process of organizational reputation reconstruction [41], even jeopardizing the organization's survival [42].

In order to prevent these costly penalties, the academic literature reports that risk assessment frameworks and registers are key elements in any risk management processes [43]. Additionally, other authors cite mitigation actions [44], establishing metrics [45] and different audit and control procedures [46,47] as crucial resources in reputational risk management. Also, the role of sustainability and corporate social responsibility has been addressed, providing heterogeneous conclusions. Thus, some evidence suggests that investing in sustainability and corporate social responsibility increases the value of the organization through intangibles as brand or reputation [48-50]. However, there is another trend of research stating that observing social and environmental issues may destroy organizational reputation, because society can interpret this behavior as the mechanism that managers use to improve their own image, obtain personal benefits or promote their professional careers, sacrificing the value of the organization [51,52].

This lack of consensus supports the existence of a dilemma that fits into the methodological framework offered by the prisoner's dilemma analysis, which is one of the best-known applications 
of game theory [53]. In fact, previous research has already adopted this approach for analyzing different aspects relating to reputation, sustainability and corporate social responsibility. In particular, organizations face a prisoner's dilemma type problem when they are dealing with ethical issues [54]. In fact, an immediate application of the prisoner's dilemma consists in presenting the prisoners as two organizations with different attitudes towards sustainability and social responsibility $[55,56]$. In a more formal schema, Klempner [57] makes a justification for sustainability and corporate social responsibility from a philosophical standpoint using the prisoner's dilemma as an explanation. In turn, Sacconi $[58,59]$ describes a contractual vision of sustainability and corporate social responsibility based on the prisoner's dilemma, as an addition to the model of corporate governance of the organization, and argues that a solution to the dilemma can be achieved through cooperation with a mutually beneficial result. As an extension of these analyses, it is argued that when the entrepreneur perceives reputation as a risk source, the subsequent behavior can be framed as a prisoner's dilemma schema. Thus, if the agents relating to the entrepreneur (namely, the stakeholders) are concerned with entrepreneurial sustainability and they observe that the entrepreneur does not defend the company against related reputational threats, when reputational damage arises they may decide to leave the entrepreneur. If an entrepreneur is concerned with entrepreneurial sustainability and decides to protect against reputational threats but the stakeholders do not reward this attitude, the entrepreneur may turn their sights towards more concerned stakeholders. If neither the entrepreneur nor the stakeholders are concerned with entrepreneurial sustainability, equilibrium arises as a non-cooperative solution of the dilemma with exposure to reputational threats. If both the entrepreneur and the stakeholders are concerned with entrepreneurial sustainability, a new solution for the dilemma arises as a cooperative outcome, with better aggregated results than the previous equilibrium insofar as there is protection against reputational threats. The different outputs of the prisoner's dilemma are summarized in Table 1.

Table 1. Outputs of the prisoner's dilemma.

\begin{tabular}{ccc}
\hline & Unconcerned Entrepreneur & Concerned Entrepreneur \\
\hline Unconcerned stakeholders & Exposure to reputational threats & Entrepreneur looks for concerned stakeholders \\
\hline Concerned stakeholders & Stakeholders leave entrepreneur & Protection against reputational threats \\
\hline
\end{tabular}

Considering that reputation is continuously exposed to risk with every decision, this process becomes an iterated prisoner's dilemma with an indeterminate number of repetitions. In this context, a non-collaborative strategy tends to perform worse in the long term, while the collaborative strategy has better results and cooperation produces an equilibrium outcome [60,61]. As a consequence, if the entrepreneur considers reputation as a risk source, the iterated prisoner's dilemma framework leads to the need for a reputational risk management strategy and, ultimately, for the entrepreneur to protect itself against reputational threats derived from entrepreneurial sustainability.

\section{Reputation as a Competitive Advantage}

According to the shared value schema, sustainability efforts promoted through corporate social responsibility could be considered a competitive advantage, given that the organization and its environment are symbiotic and mutually dependent. That is to say that environmental and social concerns are far from being a boundary for organizational performance, and they are in fact a great opportunity for business growth and development, which would create economic value through the link between social value and stakeholders' objectives [62]. The shared value scenario becomes the ideal framework to foster the exploration of new innovation paths [63], thus supporting the appearance of unexpected improvements and progress that can result in disruptive innovations. Nevertheless, the disruptive effect may not come straightforwardly, which leads to the innovator's dilemma [64]. The solution to the innovator's dilemma arises when the organization creates its own disruptive innovations, by transforming innovative ideas into successful outcomes [65], which may even result in 
catalytic innovations with positive social repercussions [66]. In this sense, and considering the already established connection between sustainability and reputation, it is argued that when the entrepreneur considers reputation as a competitive advantage, it can work as a disruptive innovation. Thus, in the first stages of the development of this competitive advantage, stakeholders may ignore or perceive it inadequately, so it may underperform in the short term. However, if this reality is not assumed in due time, when the practice spreads through the market the entrepreneur will hold a worse competitive position in the long term, with few chances to react and severe difficulties to recover from the suffered damage. Consequently, here is the source of the innovator's dilemma. As a solution for the dilemma, the entrepreneur should drive the change in search of undiscovered reputational opportunities related to entrepreneurial sustainability, by actively managing relations with a growing set of stakeholders and fulfilling their demands satisfactorily [67]. As a matter of fact, the consonance between these stakeholders' expectations and the way that the entrepreneur presents and discloses the performance is crucially related to reputation $[68,69]$, and previous researchers cite cooperation with the environment as a critical aspect to successfully build public trust and a solid reputation [70-72]. Other authors also mention the influence of environmental, social and governance factors on reputation [73-76], with communication playing a key role in order to achieve the competitive advantage related to public trust, community confidence and social approval [77]. Actually, this challenge should become a key concern for directors [78] given its usefulness during crisis management [79]. The different outputs of the innovator's dilemma are summarized in Table 2.

Table 2. Outputs of the innovator's dilemma.

\begin{tabular}{ccc}
\hline & Reactive Entrepreneur & Proactive Entrepreneur \\
\hline $\begin{array}{c}\text { Stakeholders not perceiving } \\
\text { advantange (short term) }\end{array}$ & Overperformance & Underperformance \\
\hline $\begin{array}{c}\text { Stakeholders perceiving } \\
\text { advantage (long term) }\end{array}$ & Worse competitive position & Competitive advantage \\
\hline
\end{tabular}

To sum up, entrepreneurs conceiving reputation as a competitive advantage must actively manage relations with the stakeholders in order to find innovative reputational opportunities related to entrepreneurial sustainability in proper time, to avoid falling into a worse competitive position. Therefore, perceiving reputation as a competitive advantage becomes a disruptive or even catalytic innovation. This situation leads the entrepreneur to an innovator's dilemma framework, which has only one solution when the entrepreneur uses innovative ideas to discover new reputational opportunities derived from entrepreneurial sustainability.

\section{Reputational Thinking as the Micro-Foundation of Reputational Intelligence}

Academic literature recognizes reputation as a strategic value driver for the organization [80], with persistent capabilities as a result of being a long-term concept beyond the short-term idea of public relations [81]. In order to develop this value creation potential, some crucial elements are organizational citizenship [82], environmental management [83] and a sort of ethical cleverness when making decisions [84]. These considerations allow proposing a new approach consisting in the entrepreneur and the stakeholders starting to think in reputational terms, considering reputation as a core value. That is, the entrepreneur and the stakeholders have to evaluate any action or decision according to the reputational risk that it entails and the potential reputational benefit that it could incorporate.

Consequently, it is necessary to alter the decision process undertaken by all the agents in the entrepreneur-stakeholders net, in order to incorporate this new capability. This reputational thinking premise implies introducing a deep change that may go through several phases of maturity until the different agents internalize it effectively and it results in successful outcomes. At first, the main obstacles may be the usual reluctance to change and cognitive dissonance [85-87]. Thus, a certain 
agent may not act under this reputational thinking premise despite being aware of its potential benefits. Hence, the conflict that may exist between an attitude and a belief, which is the seed for the cognitive dissonance, can trigger two different reactions. The first one relies on a constructive attitude and involves the agent identifying the origin of the conflict and making changes in order to abandon dissonance and to reach consonance adopting active reputational thinking from that moment on [88]. The second reaction relies on rejection: the agent looks for an extensive variety of reasons that justify the non-reputational thinking attitude which reinforce this behavior. Under these circumstances, there is a tendency to identify the facts and information that support the self-justification, ignoring or minimizing of the information that refutes the behavior $[89,90]$. In this second situation, rewarding reputational thinking and creating the adequate environmental conditions for the entrepreneur-stakeholders net may result in a different emotional outcome that influences not only the responses [91-93] but also the transmission of those responses [94-96]. In any case, acquiring this desired attitudinal change can be achieved through internal attitudes or external actions. Moreover, this new attitude is prone to novel learning experiences. Now, the focus turns towards training processes in order to exercise and improve this incipient reputational thinking, applying it to daily situations. This stage becomes critical because, according to existing research in the field of neuroplasticity, the learning absorption ability is always present throughout the individual's lifetime $[97,98]$ and induces persistent changes in areas of the brain that are directly related to the trained ability, as a reaction to environmental needs [99]. There is empirical evidence of the role of social influences in this process [100,101], with observable results even in the short term [102]. Thus, even the most reluctant agent to change has the ability to change under the right environmental conditions. Once the learning process starts, the mirror neuron mechanism plays a key role. If one agent can reflect the compromise with the reputational thinking premise held by another one and feel it as if it was its own feeling, this propitiates the creation of a connection between them, [103-105], taking into account that success depends on the ability to understand how the other one feels towards the new scenario [106-108]. At last, the mirror neuron framework turns that connection into imitation, allowing the transmission of knowledge and values $[109,110]$ and opening the road to sharing and improving reputational thinking. In this sense, leaders may play a key role [111,112]. At this point, dialogue and collaboration become crucial, and social neuroscience provides explanatory clues on understanding the enrichment effects of these social interactions $[113,114]$. In fact, the literature points out the concept of cooperative construction of mutual thinking [115], and even some empirical research proves its connection with organizational legitimacy and reputation [116] through the contagion of individual thinking [117]. Consequently, social cooperation becomes a requirement in order to polish reputational thinking, and this collaborative process in its maximum degree leads to a reciprocal altruism framework [118-122]. As a result, reputational thinking has a successful evolutionary outcome, with generalized welfare in the long term, as shown in Figure 1.

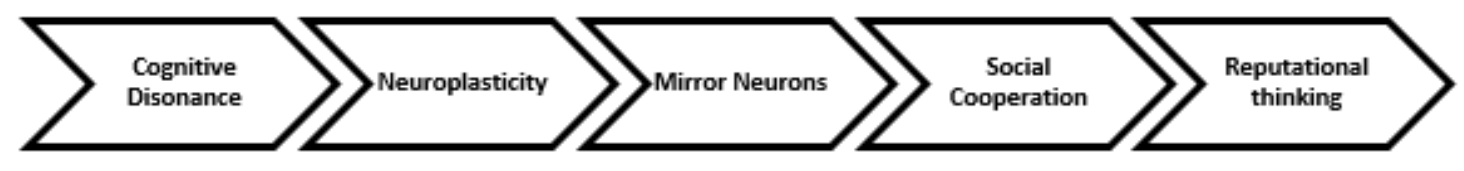

Figure 1. Development of individual reputational thinking.

In fact, the analysis can be framed as a weak-link coordination game schema, where the entrepreneur and the stakeholders decide the effort put into exercising this reputational thinking premise $[123,124]$. At its maximum, and once all the agents inside the entrepreneur-stakeholders net exercise reputational thinking actively, it permeates every action and decision, and the coordination games acquire the best equilibrium outcome, pointing to the need for a coordinated reputational thinking in order to succeed. At this stage, reputation perception goes beyond a risk source or a competitive advantage and becomes a core value that guides behavior. Reputation becomes the center of the entrepreneur's mission, so that building and maintaining a healthy reputation should be the 
main concern of the entrepreneur. Therefore, reputational thinking becomes the micro-foundation of a new business philosophy that certain sets of stakeholders may find valuable and creates the potential to develop and merge abilities in order to deal with the rapidly changing environment. This description fits well with the definition of intelligence given in the context of the theory of multiple intelligences $[125,126]$, so the result of this new approach is the development of a novel modality of intelligence, called reputational intelligence, which has the potential to become a key for succeeding in entrepreneurial sustainability, as happens with other types of intelligences, like emotional intelligence [127,128], social intelligence [127,129], ecological intelligence [130,131], cultural intelligence [132,133] or competitive intelligence [134,135]. The different outputs of the coordination game are summarized in Table 3.

Table 3. Outputs of the coordination game.

\begin{tabular}{ccc}
\hline & $\begin{array}{c}\text { Entrepreneur Deploying } \\
\text { Minimum Effort }\end{array}$ & $\begin{array}{c}\text { Entrepreneur Deploying } \\
\text { Maximium Effort }\end{array}$ \\
\hline $\begin{array}{c}\text { Stakeholders deploying } \\
\text { miminum effort }\end{array}$ & Reputation lacks strategic value & $\begin{array}{c}\text { Entrepreneur thinking } \\
\text { reputationally }\end{array}$ \\
\hline $\begin{array}{c}\text { Stakeholders deploying } \\
\text { maximum effort }\end{array}$ & $\begin{array}{c}\text { Stakeholders thinking } \\
\text { reputationally }\end{array}$ & Reputational intelligence \\
\hline
\end{tabular}

\section{Integration of the Three Dimensions of Reputation}

Reputation is a dynamic concept directly related to sustainability and corporate social responsibility, which has become the main topic of a prolific field of research with a vast number of theories. Consequently, there is a need to unite all these methodological approaches [136] in order to search for a theoretical fusion [137] that would facilitate the development of new methods based on the existing ones [138]. Similarly, integration of the three proposed dimensions of reputation perception is a possibility, given that they can appear incrementally, with each dimension as an evolutionary outcome of the previous one, as shown in Figure 2.

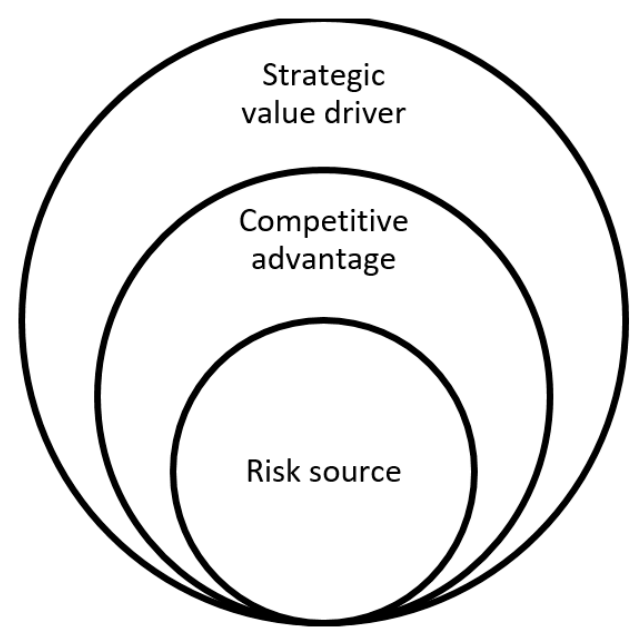

Figure 2. The three dimensions of reputation considered incrementally.

In this scenario, the entrepreneur can start by perceiving reputation as a risk source, leading the entrepreneur to look for the protection against reputational threats derived from entrepreneurial sustainability. Once the entrepreneur conquers this objective, it is time to jump to the next step, so the entrepreneur starts to perceive reputation as a competitive advantage, so that the entrepreneur is encouraged to search for reputational opportunities derived from entrepreneurial sustainability. Next, the entrepreneur can adopt a new perspective and start to think in reputational terms by perceiving 
reputation as a core value. Consequently, the entrepreneur can reach the last stage by putting reputation in the center of the entrepreneur's mission, developing the new skill of reputational intelligence in searching for the new abilities required for succeeding in the entrepreneurial sustainability scenario. Therefore, reputational intelligence becomes the equilibrium outcome of this sequence and reflects how the perception of reputation has evolved from a constricted initial idea to a broad complex framework, determining the entrepreneur's behavior at each stage as an analogy of what has also happened with sustainability and corporate social responsibility [139]. That is to say that the perception of reputation has an evolutionary nature and, as a consequence, its management becomes a key dynamic capability for the challenging objective of succeeding in the entrepreneurial sustainability scenario, as shown in Figure 3.

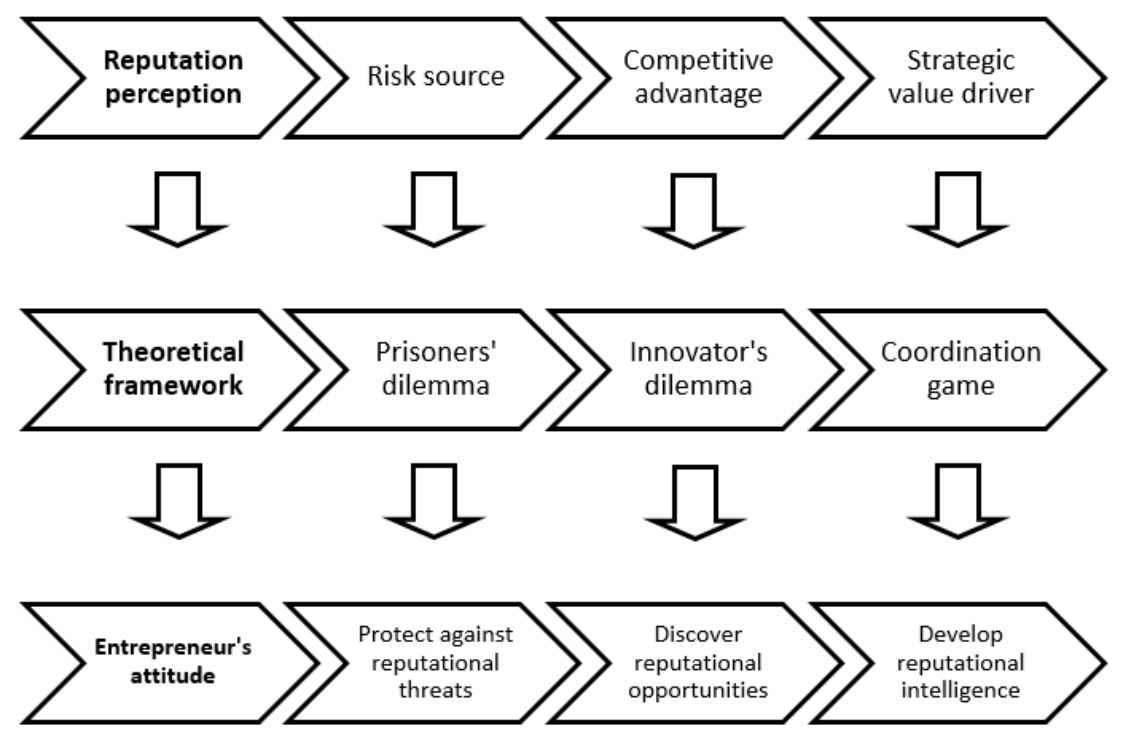

Figure 3. Transitions along the three dimensions of reputation.

\section{Conclusions}

Reputation is the core of a management area that is especially prone to adopting different approaches, supporting the appearance of novel schemas and revising existing ones. In this sense, this manuscript provides a novel approach to reputational management as a driver of entrepreneurial sustainability using game theory to integrate three dimensions of reputation. First, the entrepreneur can recognize reputation as a risk source and, therefore, the entrepreneur moves to a prisoners' dilemma framework that has a single solution when defending against the reputational threats related to entrepreneurial sustainability. A second dimension relies on perceiving reputation as a competitive advantage. Consequently, the entrepreneur enters into an innovator's dilemma schema that also has a unique solution when turning pioneering ideas into reputational opportunities derived from entrepreneurial sustainability. Ultimately, a new schema is proposed, based on reputation being perceived as a core value that guides the entrepreneur's thinking in reputational terms into a coordination game schema. The development of this reputational thinking becomes the micro-foundation of a new business philosophy, with reputation affecting every action and decision. As a final result, the outcome fits well into the theory of multiple intelligences, leading to the appearance of a new ability called reputational intelligence, which allows the entrepreneur's resources to be used in a more effective manner to succeed in the entrepreneurial sustainability scenario. Finally, the three dimensions do not need to be analyzed separately; in fact, they can appear as three stages of an evolutionary process ending in reputational intelligence as the equilibrium outcome. In sum, this manuscript provides an original multidisciplinary analysis of reputational management by relating well-known theoretical results from game theory to organizational realities. 
Acknowledgments: The authors thank the editors and anonymous referees who commented on this article.

Author Contributions: All of the authors contributed significantly to the completion of this manuscript, conceiving and designing the research, writing and improving the paper. All authors have read and approved the manuscript.

Conflicts of Interest: The authors declare no conflict of interest.

\section{References}

1. Arjoon, S. Corporate governance: An ethical perspective. J. Bus. Eth. 2005, 61, 343-352. [CrossRef]

2. Gonzalez-Perez, M.; Leonard, L. International Business, Sustainability and Corporate Social Responsibility; Emerald Group Publishing: Bingley, UK, 2013.

3. Bachev, H. Risk Management in the Agri-food Sector. Contemp. Econ. 2013, 7, 45-62. [CrossRef]

4. Chetty, S.; Naidoo, R.; Seetharam, Y. The impact of corporate social responsibility on firms' financial performance in South Africa. Contemp. Econ. 2015, 9, 193-214.

5. Surroca, J.; Tribó, J.A.; Waddock, S. Corporate responsibility and financial performance: The role of intangible resources. Strateg. Manag. J. 2010, 31, 463-490. [CrossRef]

6. Tang, A.K.; Lai, K.; Cheng, T. Environmental governance of enterprises and their economic upshot through corporate reputation and customer satisfaction. Bus. Strategy Environ. 2012, 21, 401-411. [CrossRef]

7. Cho, C.H.; Guidry, R.P.; Hageman, A.M.; Patten, D.M. Do actions speak louder than words? An empirical investigation of corporate environmental reputation. Account. Organ. Soc. 2012, 37, 14-25. [CrossRef]

8. Comeig, I.; Holt, C.A.; Jaramillo-Gutiérrez, A. Dealing with Risk: Gender, Stakes, and Probability Effects; University of Valencia, ERI-CES: Valencia, Spain, 2015.

9. Chorafas, D.N. The Management of Equity Investments; Butterworth-Heinemann: London, UK, 2004.

10. Rayner, J. Managing Reputational Risk: Curbing Threats, Leveraging Opportunities; Wiley: Chichester, UK, 2004.

11. Adams, C.A. A commentary on: Corporate social responsibility reporting and reputation risk management. Account. Audit. Account. J. 2008, 21, 365-370. [CrossRef]

12. Bebbington, J.; Larrinaga, C.; Moneva, J.M. Corporate social reporting and reputation risk management. Account. Audit. Account. J. 2008, 21, 337-361. [CrossRef]

13. Forstmoser, P.; Herger, N. Managing reputational risk: A reinsurer's view. Geneva Pap. Risk Insur.-Issues Pract. 2006, 31, 409-424. [CrossRef]

14. Hogan, J.; Lodhia, S. Sustainability reporting and reputation risk management: An Australian case study. Int. J. Account. Inform. Manag. 2011, 19, 267-287. [CrossRef]

15. Pineiro-Chousa, J.; Vizcaíno-González, M.; Romero-Castro, N. Recent Advances in Standardizing the Reporting of Nonfinancial Information. In Organizational Change and Global Standardization: Solutions to Standards and Norms Overwhelming Organizations; Boje, D.M., Ed.; Routledge: New York, NY, USA, 2015; pp. 169-185.

16. Plunus, S.; Gillet, R.; Hübner, G. Reputational damage of operational loss on the bond market: Evidence from the financial industry. Int. Rev. Financ. Anal. 2012, 24, 66-73. [CrossRef]

17. Fiordelisi, F.; Soana, M.; Schwizer, P. The determinants of reputational risk in the banking sector. J. Bank. Financ. 2013, 37, 1359-1371. [CrossRef]

18. Palm, S. Why Reputational Risk Is on the Rise. Am. Bank. 2012, 177, 6.

19. Csiszar, E.; Heidrich, G.W. The question of reputational risk: Perspectives from an industry. Geneva Pap. Risk Insur. Issues Pract. 2006, 31, 382-394. [CrossRef]

20. Schanz, K. Reputation and reputational risk management. Geneva Pap. Risk Insur. Issues Pract. 2006, 31, 377-381. [CrossRef]

21. Power, M.; Scheytt, T.; Soin, K.; Sahlin, K. Reputational risk as a logic of organizing in late modernity. Organ. Stud. 2009, 30, 301-324. [CrossRef]

22. Binkhorst, J.; Kingma, S.F. Safety vs. reputation: Risk controversies in emerging policy networks regarding school safety in the Netherlands. J. Risk Res. 2012, 15, 913-935. [CrossRef]

23. Kuckertz, A.; Wagner, M. The influence of sustainability orientation on entrepreneurial intentions-Investigating the role of business experience. J. Bus. Ventur. 2010, 25, 524-539. [CrossRef] 
24. Shepherd, D.A.; Patzelt, H. The new field of sustainable entrepreneurship: Studying entrepreneurial action linking "what is to be sustained" with "what is to be developed". Entrep. Theory Pract. 2011, 35, 137-163. [CrossRef]

25. Tregidga, H.; Milne, M.; Kearins, K. (Re)presenting 'sustainable organizations'. Account. Organ. Soc. 2014, 39, 477-494. [CrossRef]

26. Heikkurinen, P.; Ketola, T. Corporate responsibility and identity: From a stakeholder to an awareness approach. Bus. Strategy Environ. 2012, 21, 326-337. [CrossRef]

27. Heikkurinen, P. Strategic corporate responsibility: A theory review and reconsideration of the conventional perspective. In Proceedings of the EGOS Conference, Helsinki, Finland, 5-7 June 2012.

28. Gray, P.H.; Cooper, W.H. Pursuing failure. Organ. Res. Methods 2010, 13, 620-643. [CrossRef]

29. Aragon-Correa, J.A. Beyond ourselves: Building bridges to generate real progress on sustainability management issues. Organ. Environ. 2013, 26, 3-6. [CrossRef]

30. Andersson, L.; Jackson, S.E.; Russell, S.V. Greening organizational behavior: An introduction to the special issue. J. Organ. Behav. 2013, 34, 151-155. [CrossRef]

31. Davis, G.F. Do theories of organizations progress? Organ. Res. Methods 2010, 13, 690-709. [CrossRef]

32. Davies, D. Risk management-Protecting reputation: Reputation risk management-The holistic approach. Comput. Law Secur. Rev. 2002, 18, 414-420. [CrossRef]

33. Doyle, E.M.; Hughes, J.F.; Glaister, K.W. Linking ethics and risk management in taxation: Evidence from an exploratory study in Ireland and the UK. J. Bus. Eth. 2009, 86, 177-198. [CrossRef]

34. Larkin, J. Strategic Reputation Risk Management; Palgrave Macmillan: New York, NY, USA, 2003.

35. Zaman, A. Reputational Risk; Prentice-Hall/Pearson Education: London, UK, 2003.

36. Atkins, D.; Drennan, L.; Bates, I. Reputational Risk: A Question of Trust; Global Professional Publishing: London, UK, 2006.

37. Cornescu, V.; Druică, E.; Bratu, A. An Overview on the Reputation Risk. In Proceedings of the 16th International Economic Conference Industrial Revolutions, from the Globalization and Post-Globalization Perspective, Sibiu, Romania, 7-8 May 2009; pp. 61-66.

38. Weitzner, D.; Darroch, J. The limits of strategic rationality: Ethics, enterprise risk management, and governance. J. Bus. Eth. 2010, 92, 361-372. [CrossRef]

39. Rodgers, W.; Guiral, A.; Gonzalo, J.A. Different pathways that suggest whether auditors' going concern opinions are ethically based. J. Bus. Eth. 2009, 86, 347-361. [CrossRef]

40. Moeller, M.; Harvey, M. Inpatriate marketing managers: Issues associated with staffing global marketing positions. J. Int. Mark. 2011, 19, 1-16. [CrossRef]

41. Sims, R. Toward a better understanding of organizational efforts to rebuild reputation following an ethical scandal. J. Bus. Eth. 2009, 90, 453-472. [CrossRef]

42. Pantelica, C. Business Ethics, A Pillar Of Corporate Reputation. Amfiteatru Econ. J. 2008, 10, 118-124.

43. Donnelly, R.; Clement, J.; Le Heron, R.; St George, J. Redesigning risk frameworks and registers to support the assessment and communication of risk in the corporate context: Lessons from a corporate risk manager in action. Risk Manag. 2012, 14, 222-247. [CrossRef]

44. Waygood, S. Capital Market Campaigning: The Impact of NGOs on Companies, Shareholder Value and Reputational Risk; Risk Books: London, UK, 2006.

45. Regan, L. A framework for integrating reputation risk into the enterprise risk management process. J. Financ. Transform. 2008, 22, 187-194.

46. Lenz, H.; Ostrowski, M. Auditor choice by IPO firms in Germany: Information or insurance signalling? Int. J. Account. Audit. Perform. Eval. 2005, 2, 300-320. [CrossRef]

47. Linsley, P.; Kajuter, P. Restoring reputation and repairing legitimacy: A case study of impression management in response to a major risk event at Allied Irish Banks plc. Int. J. Financ. Serv. Manag. 2008, 3, 65-82. [CrossRef]

48. Zingales, L. In search of new foundations. J. Financ. 2000, 55, 1623-1653. [CrossRef]

49. Jiao, Y. Stakeholder welfare and firm value. J. Bank. Financ. 2010, 34, 2549-2561. [CrossRef]

50. Vizcaíno, M.; Chousa, J.P. Analyzing the influence of the funds' support on Tobin's q using SEM and fsQCA. J. Bus. Res. 2016, 69, 2118-2124. [CrossRef]

51. Pagano, M.; Volpin, P.F. Managers, workers, and corporate control. J. Financ. 2005, 60, 841-868. [CrossRef] 
52. Cronqvist, H.; Heyman, F.; Nilsson, M.; Svaleryd, H.; Vlachos, J. Do entrenched managers pay their workers more? J. Financ. 2009, 64, 309-339. [CrossRef]

53. Von Neumann, J.; Morgenstern, O. Theory of Games and Economic Behaviour; Princeton University Press: Princeton, NJ, USA, 1947.

54. Shaw, W.H. Marxism, business ethics, and corporate social responsibility. J. Bus. Eth. 2009, 84, 565-576. [CrossRef]

55. Kopel, M.; Brand, B. Socially responsible firms and endogenous choice of strategic incentives. Econ. Model 2012, 29, 982-989. [CrossRef]

56. Lambertini, L.; Tampieri, A. Corporate Social Responsibility and Firms Ability to Collude. In Board Directors and Corporate Social Responsibility; Palgrave Macmillan: Basingstoke, UK, 2011.

57. Klempner, G. Ethics and Advertising. 2004. Available online: http://klempner.freeshell.org/articles/ advertising.html (accessed on 16 November 2016).

58. Sacconi, L. A social contract account for CSR as an extended model of corporate governance (I): Rational bargaining and justification. J. Bus. Eth. 2006, 68, 259-281. [CrossRef]

59. Sacconi, L. Corporate Social Responsibility (CSR) as a Model of 'Extended' Corporate Governance: An Explanation Based on the Economic Theories of Social Contract, Reputation and Reciprocal Conformism. LIUC Ethics Law and Economic Paper. 2004. Available online: https:/ / papers.ssrn.com/sol3/papers.cfm? abstract_id $=514522$ (accessed on 16 November 2016).

60. Harrington, J. Games, Strategies and Decision Making; Palgrave Macmillan: New York, NY, USA, 2009.

61. Tadelis, S. Game Theory: An Introduction; Princeton University Press: Princeton, NJ, USA, 2013.

62. Porter, M.E.; Kramer, M.R. The link between competitive advantage and corporate social responsibility. Harv. Bus. Rev. 2006, 84, 78-92. [PubMed]

63. Porter, M.E.; Kramer, M.R. Creating shared value. Harv. Bus. Rev. 2011, 89, 62-77.

64. Bower, J.L.; Christensen, C.M. Disruptive Technologies: Catching the Wave; Harvard Business Review: Boston, MA, USA, 1995.

65. Christensen, C.M.; Raynor, M.E. The Innovator's Solution: Creating and Sustaining Successful Growth; Harvard Business School Press: Boston, MA, USA, 2013.

66. Christensen, C.M.; Baumann, H.; Ruggles, R.; Sadtler, T.M. Disruptive innovation for social change. Harv. Bus. Rev. 2006, 84, 94. [PubMed]

67. Christopher, M.; Gaudenzi, B. Exploiting knowledge across networks through reputation management. Ind. Mark. Manag. 2009, 38, 191-197. [CrossRef]

68. Castelo Branco, M.; Lima Rodrigues, L. Corporate social responsibility and resource-based perspectives. J. Bus. Eth. 2006, 69, 111-132. [CrossRef]

69. Boje, D.M.; Rosile, G.A.; Durant, R.A.; Luhman, J.T. Enron spectacles: A critical dramaturgical analysis. Organ. Stud. 2004, 25, 751-774. [CrossRef]

70. Jensen, J.L.; Ponsaing, C.D.; Thrane, S. Risk, resources and structures: Experimental evidence of a new cost of risk component-The structural risk component and implications for enterprise risk management. Risk Manag. 2012, 14, 152-175. [CrossRef]

71. Glückler, J.; Armbrüster, T. Bridging uncertainty in management consulting: The mechanisms of trust and networked reputation. Organ. Stud. 2003, 24, 269-297. [CrossRef]

72. Bachmann, R.; Inkpen, A.C. Understanding institutional-based trust building processes in inter-organizational relationships. Organ. Stud. 2011, 32, 281-301. [CrossRef]

73. Hebb, T.; Hamilton, A.; Hachigian, H. Responsible Property Investing in Canada: Factoring Both Environmental and Social Impacts in the Canadian Real Estate Market. J. Bus. Eth. 2010, 92, 99-115. [CrossRef]

74. Richardson, B.J. Keeping ethical investment ethical: Regulatory issues for investing for sustainability. J. Bus. Eth. 2009, 87, 555-572. [CrossRef]

75. Roberts, S. Supply chain specific? Understanding the patchy success of ethical sourcing initiatives. J. Bus. Eth. 2003, 44, 159-170. [CrossRef]

76. Madden, T.J.; Roth, M.S.; Dillon, W.R. Global product quality and corporate social responsibility perceptions: A cross-national study of halo effects. J. Int. Mark. 2012, 20, 42-57. [CrossRef]

77. Eyles, J.; Fried, J. 'Technical breaches' and 'eroding margins of safety'-Rhetoric and reality of the nuclear industry in Canada. Risk Manag. 2012, 14, 126-151. [CrossRef] 
78. Gaultier-Gaillard, S.; Louisot, J.; Rayner, J. Managing Reputational Risk-From Theory to Practice. In Reputation Capital; Klewes, J., Wreschniok, R., Eds.; Springer: Berlin, Germany, 2009; pp. 161-178.

79. Coldwell, D.; Joosub, T.; Papageorgiou, E. Responsible Leadership in Organizational Crises: An Analysis of the Effects of Public Perceptions of Selected SA Business Organizations' Reputations. J. Bus. Eth. 2012, 109, 133-144. [CrossRef]

80. Gaultier-Gaillard, S.; Louisot, J. Risks to reputation: A global approach. Geneva Pap. Risk Insur. Issues Pract. 2006, 31, 425-445. [CrossRef]

81. Stanaland, A.J.; Lwin, M.O.; Murphy, P.E. Consumer perceptions of the antecedents and consequences of corporate social responsibility. J. Bus. Eth. 2011, 102, 47-55. [CrossRef]

82. Fombrun, C.J.; Gardner, N.A.; Barnett, M.L. Opportunity Platforms and Safety Nets: Corporate Citizenship and Reputational Risk. Bus. Soc. Rev. 2000, 105, 85-106. [CrossRef]

83. Rodrigue, M.; Magnan, M.; Cho, C.H. Is Environmental Governance Substantive or Symbolic? An Empirical Investigation. J. Bus. Eth. 2013, 114, 1-23. [CrossRef]

84. Balch, D.R.; Armstrong, R.W. Ethical Marginality: The Icarus Syndrome and Banality of Wrongdoing. J. Bus. Eth. 2010, 92, 291-303. [CrossRef]

85. Festinger, L. A Theory of Cognitive Dissonance; Stanford University Press: Stanford, CA, USA, 1962.

86. Fontanari, J.F.; Bonniot-Cabanac, M.; Cabanac, M.; Perlovsky, L.I. A structural model of emotions of cognitive dissonances. Neural Netw. 2012, 32, 57-64. [CrossRef] [PubMed]

87. Sahgal, A.; Elfering, A. Relevance of cognitive dissonance, activation and involvement to branding: An overview. Escr. Psicol. 2011, 4, 15-26. [CrossRef]

88. Gawronski, B. Back to the future of dissonance theory: Cognitive consistency as a core motive. Soc. Cognit. 2012, 30, 652-668. [CrossRef]

89. Tavris, C.; Aronson, E. Mistakes Were Made (but Not by Me): Why We Justify Foolish Beliefs, Bad Decisions, and Hurtful Acts; Harvest Books: Orlando, FL, USA, 2008.

90. Lowell, J. Managers and Moral Dissonance: Self Justification as a Big Threat to Ethical Management? J. Bus. Eth. 2012, 105, 17-25. [CrossRef]

91. Champagne, F.A.; Francis, D.D.; Mar, A.; Meaney, M.J. Variations in maternal care in the rat as mediating influence for the effects of environment on development. Physiol. Behav. 2003, 79, 359-371. [CrossRef]

92. Levin, A. Early experiences change DNA and thus gene expression. Psychiatric News, 6 June $2009 ; 18$. [CrossRef]

93. Weaver, I.C.; Cervoni, N.; Champagne, F.A.; D'Alessio, A.C.; Sharma, S.; Seckl, J.R.; Dymov, S.; Szyf, M.; Meaney, M.J. Epigenetic programming by maternal behaviour. Nat. Neurosci. 2004, 7, 847-854. [CrossRef] [PubMed]

94. Francis, D.; Diorio, J.; Liu, D.; Meaney, M.J. Nongenomic transmission across generations of maternal behaviour and stress responses in the rat. Science 1999, 286, 1155-1158. [CrossRef] [PubMed]

95. Meaney, M.J. Epigenetics and the biological definition of gene $\times$ environment interactions. Child Dev. 2010, 81, 41-79. [CrossRef] [PubMed]

96. Suderman, M.; McGowan, P.O.; Sasaki, A.; Huang, T.C.; Hallet, M.T.; Meaney, M.J.; Turecki, G.; Szyf, M. Conserved epigenetic sensitivity to early life experience in the rat and human hippocampus. Proc. Natl. Acad. Sci. USA 2012, 109, 17266-17272. [CrossRef] [PubMed]

97. Hensch, T. Controlling the critical period. Neurosci. Res. 2003, 47, 17-22. [CrossRef]

98. Hölzel, B.K.; Carmody, J.; Vangel, M.; Congleton, C.; Yerramsetti, S.M.; Gard, T.; Lazar, S.W. Mindfulness practice leads to increases in regional brain gray matter density. Psychiatry Res. Neuroimaging 2011, 191, 36-43. [CrossRef] [PubMed]

99. Draganski, B.; Gaser, C.; Busch, V.; Schuierer, G.; Bogdahn, U.; May, A. Neuroplasticity: Changes in grey matter induced by training. Nature 2004, 427, 311-312. [CrossRef] [PubMed]

100. Davidson, R.J.; McEwen, B.S. Social influences on neuroplasticity: Stress and interventions to promote well-being. Nat. Neurosci. 2012, 15, 689-695. [CrossRef] [PubMed]

101. Khazanchi, S.; Masterson, S.S. Who and what is fair matters: A multi-foci social exchange model of creativity. J. Organ. Behav. 2011, 32, 86-106. [CrossRef]

102. Sagi, Y.; Tavor, I.; Hofstetter, S.; Tzur-Moryosef, S.; Blumenfeld-Katzir, T.; Assaf, Y. Learning in the fast lane: New insights into neuroplasticity. Neuron 2012, 73, 1195-1203. [CrossRef] [PubMed] 
103. Iacoboni, M.; Mazziotta, J.C. Mirror neuron system: Basic findings and clinical applications. Ann. Neurol. 2007, 62, 213-218. [CrossRef] [PubMed]

104. Keysers, C.; Gazzola, V. Social neuroscience: Mirror neurons recorded in humans. Curr. Biol. 2010, 20, R353-R354. [CrossRef] [PubMed]

105. Liew, S.; Aziz-Zadeh, L. The Human Mirror Neuron System, Social Control, and Language. In Handbook of Neurosociology; Franks, D.D., Turner, J.H., Eds.; Springer: New York, NY, USA, 2013; pp. 183-205.

106. Bernhardt, B.C.; Singer, T. The neural basis of empathy. Annu. Rev. Neurosci. 2012, 35, 1-23. [CrossRef] [PubMed]

107. Singer, T. The neuronal basis and ontogeny of empathy and mind reading: Review of literature and implications for future research. Neurosci. Biobehav. Rev. 2006, 30, 855-863. [CrossRef] [PubMed]

108. Singer, T.; Lamm, C. The social neuroscience of empathy. Ann. N. Y. Acad. Sci. 2009, 1156, 81-96. [CrossRef] [PubMed]

109. Iacoboni, M.; Woods, R.P.; Brass, M.; Bekkering, H.; Mazziotta, J.C.; Rizzolatti, G. Cortical mechanisms of human imitation. Science 1999, 286, 2526-2528. [CrossRef] [PubMed]

110. Gerrans, P.S. Imitation, mind reading, and social learning. Biol. Theory 2013, 8, 20-27. [CrossRef]

111. Christensen, L.J.; Mackey, A.; Whetten, D. Taking responsibility for corporate social responsibility: The role of leaders in creating, implementing, sustaining, or avoiding socially responsible firm behaviors. Acad. Manag. Perspect. 2014, 28, 164-178. [CrossRef]

112. Robertson, J.L.; Barling, J. Greening organizations through leaders' influence on employees' pro-environmental behaviors. J. Organ. Behav. 2013, 34, 176-194. [CrossRef]

113. Stanley, D.A.; Adolphs, R. Toward a neural basis for social behavior. Neuron 2013, 80, 816-826. [CrossRef] [PubMed]

114. Norman, G.J.; Hawkley, L.C.; Cole, S.W.; Berntson, G.G.; Cacioppo, J.T. Social neuroscience: The social brain, oxytocin, and health. Soc. Neurosci. 2012, 7, 18-29. [CrossRef] [PubMed]

115. Johnson-Cramer, M.; Berman, S.; Post, J. Re-examining the Concept of 'Stakeholder Management'. In Unfolding Stakeholder Thinking: Relationships, Communication, Reporting and Performance; Andriof, J., Waddock, S., Husted, B., Rahman, S., Eds.; Greenleaf Publishing: Sheffield, UK, 2003; pp. 145-161.

116. Morsing, M.; Schultz, M. Corporate social responsibility communication: Stakeholder information, response and involvement strategies. Bus. Eth. A Eur. Rev. 2006, 15, 323-338. [CrossRef]

117. Lee, B. The Hidden Wealth of Customers: Realizing the Untapped Value of Your Most Important Asset; Harvard Business Press: Boston, MA, USA, 2012.

118. Ricard, M. The Art of Happiness: A Guide to Developing Life's Most Important Skill; Atlantic Books: London, UK, 2011.

119. Trivers, R.L. The evolution of reciprocal altruism. Q. Rev. Biol. 1971, 16, 35-57. [CrossRef]

120. Batson, C.D. Altruism in Humans; Oxford University Press: Oxford, UK, 2011.

121. Compton, W.C.; Hoffman, E. Positive Psychology: The Science of Happiness and Flourishing; Wadsworth Publishing Company: Wadsworth, OH, USA, 2012.

122. Rilling, J.K.; Gutman, D.A.; Zeh, T.R.; Pagnoni, G.; Berns, G.S.; Kilts, C.D. A neural basis for social cooperation. Neuron 2002, 35, 395-405. [CrossRef]

123. Benavides Espinosa, M.D.M.; Comeig, I.R.; Darós, L.C. Adaptación organizativa a los cambios tecnológicos en la industria cultural: Un estudio a partir de la economía experimental. Econ. Ind. 2013, 389, 95-106.

124. Van Huyck, J.B.; Battalio, R.C.; Beil, R.O. Tacit coordination games, strategic uncertainty, and coordination failure. Am. Econ. Rev. 1990, 80, 234-248.

125. Gardner, H. Intelligence Reframed: Multiple Intelligences for the 21st Century; Basic Books: New York, NY, USA, 2000.

126. Gardner, H. Frames of Mind: The Theory of Multiple Intelligences; Basic Books: New York, NY, USA, 2011.

127. Emmerling, R.J.; Boyatzis, R.E. Emotional and social intelligence competencies: Cross cultural implications. Cross Cult. Manag. Int. J. 2012, 19, 4-18. [CrossRef]

128. Goleman, D. Emotional Intelligence: Why It Can Matter More Than IQ; Bantam Books: New York, NY, USA, 1996.

129. Goleman, D. Social Intelligence: The New Science of Social Relationships; Bantam Books: New York, NY, USA, 2006.

130. Goleman, D. Ecological Intelligence: How Knowing the Hidden Impacts of What We Buy Can Change Everything; Random House Digital, Inc.: New York, NY, USA, 2009. 
131. Todd, P.M.; Gigerenzer, G. Ecological Rationality: Intelligence in the World; Oxford University Press: Oxford, UK, 2012.

132. Earley, P.C.; Ang, S. Cultural Intelligence: Individual Interactions Across Cultures; Stanford University Press: New York, NY, USA, 2003.

133. Livermore, D. Leading with Cultural Intelligence: The New Secret to Success; AMACOM: New York, NY, USA, 2009.

134. Fleisher, C.S.; Bensoussan, B.E. Business and Competitive Analysis: Effective Application of New and Classic Methods; FT Press: New York, NY, USA, 2007.

135. Fuld, L.M. Competitor Intelligence: How to Get It, How to Use It; John Wiley \& Sons Inc.: New York, NY, USA, 1985.

136. Garriga, E.; Melé, D. Corporate social responsibility theories: Mapping the territory. J. Bus. Eth. 2004, 53, 51-71. [CrossRef]

137. Windsor, D. Corporate social responsibility: Three key approaches. J. Manag. Stud. 2006, 43, 93-114. [CrossRef]

138. Carroll, A.B. Corporate social responsibility evolution of a definitional construct. Bus. Soc. 1999, 38, $268-295$. [CrossRef]

139. Cochran, P.L. The evolution of corporate social responsibility. Bus. Horiz. 2007, 50, 449-454. [CrossRef]

(c) 2016 by the authors; licensee MDPI, Basel, Switzerland. This article is an open access article distributed under the terms and conditions of the Creative Commons Attribution (CC-BY) license (http:/ / creativecommons.org/licenses/by/4.0/). 